\title{
Theories of Population and Agricultural Conditions: A re-examination with evidences from Eastern Nigeria
}

\author{
C. Nwajiuba \\ Department of Agricultural Economics \\ Imo State University Owerri, P.M.B. 2000 Owerri, Nigeria \\ E-mail: chnwajiuba@yahoo.de
}

\begin{abstract}
There are two broad categories of views among researchers on the relationship between population and agriculture. The first holds that population is dependent on agriculture, while a second view is that conditions of agriculture and rural livelihood are dependent on population. However such views particularly on traditional African farming systems were rarely derived from long-term field survey on specific communities. The research on which this paper is based uses a 1974 survey as a benchmark. A cross-sectional survey of the same three communities of varying population densities studied in 1974 was conducted in 2004. Results show decreased fallow years, intensified use of technologies and increased farm output. However issues that appeared less important three decades ago have emerged with significant influence on livelihood. Migration and increased reliance on off-farm jobs are of particular importance. It is therefore important that research and policy address issues such as modernization of the farm sector through labour saving devices, and provision of farm technologies including inorganic fertilizer.
\end{abstract}

Key Words: farming systems, agricultural conditions, population growth

\section{Introduction}

The relationship between population growth and agricultural conditions has attracted the attention of researchers for decades. Prominent among these are Boserup (1993), Lagemann (1977), Ruthenberg (1980), and Schultz (1983). The prominent theory particularly with respect to traditional farming systems as found in most of sub-Saharan Africa, is that population growth affects land accessibility and utilization, the use of technology inputs and the degree of market orientation (Doppler, 1991; Ruthenberg, 1980).

These views have been the focus of research and policy in sub-Saharan Africa. However, rarely have agricultural and social researchers conducted long-term micro-level studies in subSaharan Africa to clarify the consistency or otherwise of these views. This paper examines how population growth affects agricultural conditions, such as land availability and utilization, technological change, farm output and degree of market orientation.

\section{Methodology}

The study was conducted in three communities in the humid rainforest area of eastern Nigeria. These three communities are Owere-ebiri and Umuokile in Imo State, and Okwe in Abia State. These three communities were purposely selected because they are the same communities 
studied by Lagemann (1977) in collaboration with the International Institute of Tropical Agriculture, Nigeria, in 1974.

In selecting the three communities three decades ago, Lagemann (1977) defined them as high (Owere-ebiri), medium (Umuokile) and low (Okwe) population density areas respectively (Table 1).

Table 1: Population and Area of Selected Communities, 1971 and 1991

\begin{tabular}{|l|l|l|}
\hline Community & $\begin{array}{l}\text { Population } \\
\text { (person) 1991 (a) }\end{array}$ & $\begin{array}{l}\text { Population Density } \\
\left(\text { persons } / \mathrm{km}^{2}\right) 1973(\mathrm{~b})\end{array}$ \\
\hline Owere Ebiri (H) & 6,965 & 1200 \\
\hline Umuokile (M) & 1448 & 500 \\
\hline Okwe (L) & 520 & 250 \\
\hline
\end{tabular}

Sources: (a) National Population Commission (NPC) (1991).

(b) Lagemann (1977).

$\begin{array}{rll}\text { Note } \mathrm{H} & = & \text { High Population Density } \\ \mathrm{M} & = & \text { Medium Population Density } \\ \mathrm{L} & = & \text { Low Population Density }\end{array}$

Field survey was conducted between the last quarter of 2003 and first half of 2004. Forty farm - households were randomly selected from each community using household lists in each of them. This gave a total sample size of 120 households. In addition appropriate references were made to secondary sources of information. Enumerators and research assistants used interview schedules, field measurements and observations as instruments for data collection. Data was subjected to simple statistical analysis.

\section{Results and Discussions}

\section{Land Tenure and Availability}

The proportion of land obtained through inheritance was $80 \%$ in Okwe, $70 \%$ in Umuokile to $57.5 \%$ in Owere-Ebiri (low, medium and high population densities respectively) (Table 2). This implies a decrease in the proportion of land obtained through inheritance as population density increased. However, there is no clear pattern between population density and the other means of farmland acquisition (gifts, lease, pledged and purchased). Communal land ownership was also not indicated in any of the three communities as a means of land acquisition. Lagemann (1977) found increased transition from communal to private land ownership and this has continued. Then in 1974, $72 \%$ of all land in the three communities was inherited. Currently only in low density Okwe is it up to $80 \%$. 
Table 2: Land tenure systems, $2004(n=120)$

\begin{tabular}{|l|l|l|l|l|}
\hline Community & Inheritance & Gift & Lease & $\begin{array}{l}\text { Pledge/ } \\
\text { Purchased } \\
(\%)\end{array}$ \\
\hline Owere - ebiri (H) & 57.5 & 5 & 17.5 & 20 \\
Umuokile(M) & 70.5 & 10.0 & 10 & 10 \\
Okwe (L) & 80.0 & 2 & 15 & 23 \\
\hline
\end{tabular}

Note $\mathrm{H}=$ High, $\mathrm{M}=$ Medium, $\mathrm{L}=$ Low

Source: Field survey, 2004

Farm Plots and sizes: About $92.5 \%$ of farmers in the high density Owerre-ebiri and medium density Umuokile owned 5 plots or less. As population density decreases the number of plots owned increases, such that $7.5 \%$ of the farmers in Owerre-ebiri and Umuokile owned between 6 to 10 plots, while in the low density Okwe, $30 \%$ of the households owned between 6 to 10 plots (Table 3). Lagemann (1977) found farmers in Okwe (L) having an average of 4 - 5 plots, 6 - 7 plots in both Umuokile (M) and Okwe (L). These therefore seem to be an evolution towards fewer plots in all communities.

Table 3: Number of plots owned by Households $(n=120)$

\begin{tabular}{|c|c|c|c|c|}
\hline & \multicolumn{4}{|c|}{ Number of plots and \% } \\
\hline Community & $1-5$ & $\%$ & $6-10$ & $\%$ \\
\hline Owere-ebiri (H) & 37 & 92.5 & 3 & 7.5 \\
\hline Umuokile (M) & 37 & 92.5 & 3 & 7.5 \\
\hline Okwe (L) & 30 & 70 & 10 & 30 \\
\hline $\begin{array}{l}\text { Total households } \\
\% \text { of households }\end{array}$ & $\begin{array}{l}107 \\
89.17\end{array}$ & & $\begin{array}{l}13 \\
10.83\end{array}$ & \\
\hline
\end{tabular}

Source: Field survey, 2004

These plots comprised compound (c) and outer (o) farms. Lagemann found compound, near fields and outer fields differentiated by the distances from the household. However, presently we have classified the plots into compound and outer plots. The average sizes of compound (c) plots are generally smaller than outer (c) plots (Table 4). However plot sizes - both compound and outer plots are inversely related to population density. Plot sizes on the average in lowdensity areas are more than double those in high population density areas. 
Table 4: Average plot size by community, 1974 and 2004

\begin{tabular}{|l|l|l|}
\hline \multirow{2}{*}{ Community } & \multicolumn{2}{|c|}{ Average plot size (ha) } \\
\cline { 2 - 3 } & $\mathbf{2 0 0 4}$ & $\mathbf{1 9 7 4}$ \\
\hline Owere - ebiri (H) & $0.026(\mathrm{c})$ & 0.034 \\
& $0.042(\mathrm{o})$ & \\
& $0.04(\mathrm{c})$ & 0.062 \\
Umuokile (M) & $0.076(\mathrm{o})$ & \\
& $0.06(\mathrm{c})$ & 0.088 \\
Okwe (L) & $0.152(\mathrm{o})$ & \\
\hline
\end{tabular}

Source: Field survey, 2004

Lagemann (1977) found average plot sizes of $880 \mathrm{~m}^{2}$ in Okwe (L), $620 \mathrm{~m}^{2}$ in Umuokile (M) and $340 \mathrm{~m}^{2}$ in Owere-ebiri $(\mathrm{H})$. These are approximately 0.08 ha, 0.062 ha and 0.034 ha respectively. These average plot sizes as found by Legamann in 1974 are all within range of the sizes of compound and outer farms. In effect not much has changed in terms of plot sizes, but the number of plots owned by each household has decreased. This could be attributed to a change in the traditional inheritance pattern where previous plots are split among sons. This meant a decline in plot sizes over generations. Now there is a tendency for sons to take specific plots rather than split them. Then it was a means of spreading land of ranging characteristics and quality. But now, with up to $70 \%$ of indigenes migrating out of their ancestral homes to urban areas for non-agricultural jobs, the incentive to obtain plots of specific characteristics has declined, although interest in inheriting family land has not declined.

Cropping Systems: About $52.5 \%$ of the respondents practice continuous cropping, while $47.5 \%$ practice fallow systems (Table 5 ). The trend is that $37.5 \%$ of households in the high population density Owere-ebiri practice continuous cropping systems, while only $62.5 \%$ practice fallow systems. This trend reverses with low population density area of Okwe with only $2 \%$ practicing continuous cropping system, while $98 \%$ of the households practice fallow systems.

The evolution from fallow systems to continuous cropping systems is clearly related to rising population density, declining number of plot per households, and dwindling average plot size. For farm - households practicing fallow systems, these ranged from an average of 1 year for high density Owere-ebiri, 2 years for medium density Umuokile and an average of 5 years for low density Okwe. 
Table 5: Land Use Systems and Fallow Years $(\mathbf{n}=120), 2004$

\begin{tabular}{|l|l|l|l|l|}
\hline \multicolumn{1}{|c|}{ Community } & \multirow{2}{*}{$\begin{array}{c}\text { Continuous } \\
\text { Cropping }\end{array}$} & \multirow{2}{*}{$\begin{array}{c}\text { Fallow } \\
\text { Systems \% }\end{array}$} & \multicolumn{2}{|c|}{ Modal Fallow Years } \\
\cline { 4 - 5 } & & & $\mathbf{1 9 7 4}^{\mathbf{a}}$ & $\mathbf{2 0 0 4}^{\mathbf{b}}$ \\
\hline Owere-ebiri & 37.5 & 62.5 & 1 & 1 \\
Umuokile & 40 & 60 & 4 & 2 \\
Okwe & 2 & 98 & 6 & 5 \\
\hline
\end{tabular}

Sources: (a) Lagemann, 1977

(b) Field Survey 2004

Ruthernberg (1980) and Doppler (1991) established Rotation-value (R) as an index of land use intensification, where,

$\mathrm{R}=\frac{\mathrm{C}}{\mathrm{C}+\mathrm{B}} \times \frac{100}{1}$

$\begin{array}{lll}\text { Note that } \mathrm{R} & = & \text { Rotation value (a parameter for land use intensification) } \\ \mathrm{C} & = & \text { Years of cultivation } \\ \mathrm{B} & = & \text { Years of Fallow }\end{array}$

Therefore for high density Owere-ebiri

$$
\mathrm{R}=\frac{1}{1+1} \times \frac{100}{1}=50 \%
$$

For medium density Umuokile

$$
\mathrm{R}=\frac{1}{2+1} \times \frac{100}{1}=33.3 \%
$$

For low density Okwe

$$
\mathrm{R}=\frac{1}{5+1} \times \frac{100}{1}=16.67 \%
$$

The larger the $\mathrm{R}$ - value the larger the extent of land use intensification. Thus Owere-ebiri $(\mathrm{H})$ with $50 \%$ has higher land-use intensification, followed by Umuokile (M) $33 \%$, and then Okwe (L) $16.67 \%$. Usually compound plots in all three villages are continuously cropped (rarely in fallow). Soil fertility in those compound farms are maintained mostly through the use of household organic materials and manure. This is consistent with what Lagemann (1977) found. Lagemann (1977) also found variation in the modal frequency years in the three villages, which decreases as population increases. These were 6 years for Okwe (L), 4 years for Umuokile (M) and 1 year in Owerri-ebiri (H) respectively (Table 5). In about 30 years, fallow years have halved in medium density Umuokile from 4 to 2 years, virtually unchanged in high density Owerri-ebiri ( 1 year), and decreased marginally in low density Okwe (6 years to 5 years). The pressure on land use that should occur due to population growth has been diffused by huge migration to urban areas. Consequently, the rate of decline in fallow years has been less than it could potentially have been. 
Migration, land and labour: From a wider study on migration in eastern Nigeria, in which the study communities are located, it was noted that on the average each community have population of 3188.57 persons. Of this, 702.41 persons or $22.03 \%$ reside in the community. The average family size in the communities is 6.9 persons. This means an average 1.52 persons $(22.03 \%)$ per family reside in the community. Another $2.21(32.03 \%)$ resided within the southeast region but not in their home communities, $0.95(13.77 \%)$ resided in locations within Nigeria but not within the southeast, 2.22 (32.17\%) resided outside Nigeria and therefore constitute international migrants (Fig. 1). The significant level of rural out migration has diffused potential pressure on rural farm land demand but has created problems of rural labour scarcity and cost especially in peak farming periods of April to September. This challenges research on labour saving devices.
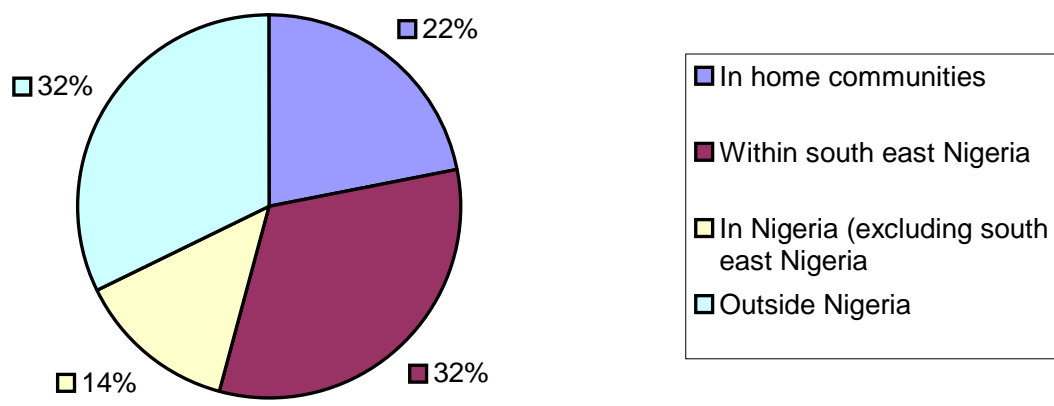

Fig 1: Destination of Migrants from southeast Nigeria, 2004/2005

Source: Nwajiuba 2005

\section{Changes in Technology Use}

Mineral Fertilizer Use: About $85 \%$ of farm-households in the high density Owere-ebiri used inorganic fertilizer in the survey period (Table 6). In the medium density Umuokile $72.5 \%$ of the farmers used inorganic fertilizer, while $40 \%$ of farm households in low density Okwe used inorganic fertilizer mostly for maize in the outer farms. Baring common problems with the inorganic fertilizer market in Nigeria (supply hiccups and high cost). This pattern shows that the higher the population density the greater the use of inorganic fertilizer. This is also related to the fallow years and ability of the soils to re-generate fertility. That is, fallow years are inversely related to inorganic fertilizer use. 
Table 6: Farm - Household use of inorganic fertilizer, $2004(n=120)$

\begin{tabular}{|l|l|l|}
\hline \multicolumn{1}{|c|}{ Community } & \multicolumn{1}{c|}{ Households } & \multicolumn{1}{c|}{ \% } \\
\hline Owere-ebiri (H) & 34 & 85 \\
Umuokile (M) & 29 & 72.5 \\
Okwe (L) & 16 & 40 \\
\hline
\end{tabular}

Source: Field survey, 2004

Pesticide and Herbicide use: The use of other agro-chemicals such as pesticides and herbicides shows that $12.5 \%$ of farm- households in the high density Owere-ebiri (Table 7), compared to $24 \%$ in medium density Umuokile and $20 \%$ in low density Okwe, used pesticide and herbicides. This has not shown any clear pattern with population density.

The commonest pesticide used is Aldrin Dust, which is applied to protect yam (Diascorea spp) seedlings from weevils. This perhaps explains the higher use of pesticides in Umuokile compared to Owere-ebiri and Okwe. Umuokile is in the Mbaise area of eastern Nigeria notable for a strong yam culture. The socio-cultural status of yam as a male crop and status symbol is strong in the area.

Table 7: Distribution of farm-households by the use of pesticides and herbicides (\%), 2004

\begin{tabular}{|l|c|c|}
\hline \multicolumn{1}{|c|}{ Community } & Respondent & \% \\
\hline Owere-ebiri & 5 & 12.5 \\
Umuokile & 16 & 24 \\
Okwe & 8 & 20 \\
\hline Total & 36 & \multicolumn{1}{|c|}{} \\
\cline { 1 - 3 }
\end{tabular}

Source: Field survey, 2004

Use of improved seeds and seedlings: The most important crop on farmers' fields in the three communities is cassava (Manihot esculenta). Substantial research and extension effort has been focused in recent years in breeding and disseminating high yielding, disease resistant, early maturing strains of cassava, The most common of which are the Tropical Manihot Series (TMS) developed at the International Institute of Tropical Agriculture (IITA) Ibadan, and the National Root Crops Research Institute (NRCRI), Umudike, Nigeria.

The high density Owere-ebiri had a high level of use of these improved varieties with about $65 \%$ of the farm-household growing them. This is followed by low density Okwe (82.5\%), and medium density Umuokile (52.5\%). It is noteworthy that the National Root Crops Research Institute Umudike is just about $4 \mathrm{~km}$ from Okwe and may be an influence on the availability and use of improved cassava planting materials. However, we can reasonably infer that since the high density Owere-ebiri has the highest level of use, other factors may have effect on this. 
This could be the orientation to the market, because cassava has evolved from a typical subsistence food crop to a cash income-earning crop.

\section{Crop Production}

The outputs of the major crops produced in the three communities were compared. These are cassava, maize, yam and plantain. The high density Owerre-ebiri produced on the average per farm-household of $113.06 \mathrm{~kg}$ of cassava, $51.23 \mathrm{~kg}$ of maize, $20.61 \mathrm{~kg}$ of yam and $13.04 \mathrm{~kg}$ of plantain (Table 8). Average output per farm-household in medium density Umuokile was $206.04 \mathrm{~kg}$ of cassava, $73.44 \mathrm{~kg}$ of maize, $39.73 \mathrm{~kg}$ of yam and $16.41 \mathrm{~kg}$ of plantain. In low density Okwe, average output per farm-household was $565 \mathrm{~kg}$ of cassava, $150 \mathrm{~kg}$ of yam, $30 \mathrm{~kg}$ of maize and $45 \mathrm{~kg}$ of plantain.

An indication of crop production performance was obtained by a simple summation of output of the four major crops. This was then related to the average area of land cropped by farm households. Despite the weakness of this approach, it is considered sufficiently indicative. Average output per hectare was highest in the medium density Umuokile $(689.29 \mathrm{~kg} / \mathrm{ha})$ followed by low density $(673.52 \mathrm{~kg} / \mathrm{ha})$ and high density Owere-ebiri $(528.18 \mathrm{~kg} / \mathrm{ha}$ (Table 8$)$. Although we see that there is not much difference in average output per hectare, the medium density Umuokile was able to combine improved farm inputs with land resources better than the low and high-density areas.

It can be inferred that longer fallow years at Okwe has identical effect as the more inorganic fertilizer use at the shorter fallow systems of Owere-ebiri and Umuokile. Further, the medium density Umuokile seemed to have developed a better combination of fallow and inorganic fertilizer as soil fertility management strategy. In effect the use of technology inputs improved planting materials and inorganic fertilizer - increases with population density and compensate for decline in fallow years.

Table 8: Average output of major crops per household (kg), 2004

\begin{tabular}{llllllll}
\hline Community & Cassava & Maize & Yam & Plantain & $\begin{array}{l}\text { Total } \\
\text { (T) }\end{array}$ & $\begin{array}{l}\text { Land Area } \\
\text { (ha) }(\mathbf{L})\end{array}$ & T/L \\
\hline Owere-ebiri & 113.06 & 51.23 & 20.61 & 13.04 & 197.94 & 0.34 & 582.18 \\
Umuokile & 206.04 & 73.44 & 39.73 & 16.41 & 336.77 & 0.49 & 697.29 \\
Okwe & 565 & 150 & 30 & 45 & 559.02 & 0.83 & 595.21 \\
\hline
\end{tabular}

Source: Field survey, 2004

\section{Orientation to the market}

The uses of the harvest of the four major crops were examined to see if there are marketable surpluses (Table 9). The results for all crops in all communities show a positive marketable surplus except for yam in low population density Okwe with a net purchase of $29.1 \%$ of 
household yam consumption. Further there is a range of $19.9 \%$ to $82.75 \%$ for maize in Owereebiri $(\mathrm{H})$ and Okwe (L). This indicates an inverse relationship between the quantities sold and population densities. We can infer that quantity of marketable surplus is dependent on total output, (after meeting household consumption needs). Because output in high population density area is determined by area cropped, intensification, and tendency for off-farm employment, volume of crop production is less and therefore there is little market surpluses. In effect while increased population density means more reliance on improved technologies, which compensates for smaller area cropped and shorter fallow years, orientation to the market has not significantly responded. The farmers are still oriented to subsistence production. Rather it is in the low-density area that surpluses are available for sale in the market.

Table 9: Output of crops and quantity sold (Kg and \%), 2004

\begin{tabular}{llllllllllllll}
\hline Community & \multicolumn{3}{c}{ Cassava } & \multicolumn{3}{c}{ Maize } & \multicolumn{3}{c}{ Yam } & \multicolumn{3}{c}{ Plantain } \\
& Total & Sold & $\%$ & Tota & Sold & $\%$ & Total & Sold & $\%$ & Tota & Sold & $\%$ \\
& & & & 1 & & & & & & 1 & \\
\hline Owere-ebiri & 113.0 & 37.68 & 33.3 & 51.2 & 10.24 & $\mathbf{1 9 . 9}$ & 20.61 & 6.87 & 33.3 & 13.0 & 4.34 & 33.3 \\
Umuokile & 6 & 68.68 & 3 & 3 & 24.48 & $\mathbf{9}$ & 29.73 & 9.91 & 3 & 4 & 5.47 & 3 \\
Okwe & 206.0 & 372.6 & 66.7 & 73.4 & 124.1 & 66.7 & 30 & 38.7 & 66.7 & 16.4 & 33.3 & 66.7 \\
& 4 & 9 & 65.9 & 4 & 2 & $\mathbf{8 2 . 7}$ & & 2 & $\mathbf{( 2 9 . 1}$ & 1 & 9 & 74.2 \\
& 565 & & 6 & 150 & & $\mathbf{5}$ & & & $\mathbf{)}$ & 45 & & \\
\hline
\end{tabular}

Source: Field survey, 2004

\section{Conclusion}

This paper has confirmed existing theories that population leads to decreased agriculture land availability, fallow years and farm output. In response, farmers resort to the use of inorganic fertilizer and improved planting materials (seeds and seedlings) to maintain and improve farm yield. Population pressure without technological progress will lead to decline in farm output.

However, contrary to expectations not much change has occurred in land use intensification between 1974 and 2004. For instance, although statistics from the National Population Commission indicate that population may have increased, fallow years have not changed much. This is ascribed to migration and resort to non-farm activities. Many persons have moved out of the rural farm sectors. The expected pressure on land-use is therefore offset by rural out migration and non-farm occupations.

Consequently, at least five issues arise which are of contemporary and future challenge to research and policy. These are urbanization and its consequences on farm-land availability and utilization; migration and its consequences for labor availability and technology development; 
soil fertility management and use of inorganic and organic fertilizer; and technology inputs availability and extension service.

\section{References}

Boserup, E. (1993) (first published 1965). Conditions of Agricultural growth: The economics of agrarian change under population pressure. Earthscan publications Ltd., London.

Doppler, W. (1991). Landwritschaftliche Betrieebssysbeme in den Tropen und Subtropen Verlag Eugen Ulmer, Stuttgart, Germany.

Lagemann, J. (1977). Traditional African Farming Systems in Eastern Nigeria. Welt Forum Verlag Munchen, Germany.

National Population Commission (NPC) (1991). Final Results of 1991 Population Census of Nigeria. Abuja Nigeria.

Nwajiuba, C. (2005). Migration and livelihood: Conceptual and policy issues. In: Nwajiuba Chinedum (ed.) Migration and livelihood in Eastern Nigeria. Margraf publishers Weikersheim, Germany, PP 1- 10.

Ruthernberg, H. (1980). Farming Systems in the Tropics. $3^{\text {rd }}$ Edition Claredon Press Oxford. Schultz, T. W. (1983) (first published 1965). Transforming traditional agriculture. The University of Chicago Press, Chicago and London. 